Türk Coğrafya Dergisi
Turkish Geographical Review
Bww.tcd.org.tr
Basilı ISSN 1302-5856

\title{
İç Anadolu Bölgesi’nin ekstrem sıcaklık özellikleri
}

\section{Extreme temperature characteristics of Central Anatolia Region}

\author{
Zahide Acar*a (i) \\ ${ }^{a}$ Çanakkale Onsekiz Mart Üniversitesi, Fen-Edebiyat Fakültesi, Coğrafya Bölümü, Çanakkale.
}

\section{BILGI / INFO}

Geliş/Received: 25.06.2018

Kabul/Accepted: 18.12.2018

\section{Anahtar Kelimeler: \\ İç Anadolu Bölgesi \\ Ekstrem sıcaklık \\ Mann-Kendall \\ Trend}

\section{Keywords:}

Central Anatolia Region

Extreme temperture

Mann-Kendall

Trend

\section{*Sorumlu yazar/Corresponding author:} (Zahide ACAR) zdeniz@comu.edu.tr

\section{DOI: $10.17211 /$ tcd. 436198}

\section{Atff/Citation:}

Acar, Z. (2018). İç Anadolu Bölgesi'nin ekstrem sıcaklık özellikleri. Türk Coğrafya Dergisi (71), 93-99.DOI:10.17211/tcd.436198

\section{ÖZ / ABSTRACT}

İç Anadolu Bölgesi, Türkiye'nin coğrafi bölgelerinden biridir. Türkiye'nin iç kesimlerini kapsayan bölgede 13 il yeralır. Çalışma kapsamında bölgenin tüm coğrafyasını temsil edecek şekilde 52 istasyon verisinden yararlanıımıştır. Genel olarak, çalışma alanının hava sıcaklıklarındaki artı̧̧ eğilimi (özellikle gece sıcaklıkları) dikkat çekicidir. Son zamanlarda daha sık yaşanan sıcak-soğuk hava dalgaları ve şiddetli yaz kuraklıkları sosyo-ekonomik açıdan önemli problemlere neden olacak düzeydedir. ÇaIışmanın amacı, i̇ç Anadolu Bölgesi'nin yaz ve kış mevsimlerindeki sıcaklıkların alansal ve zamansal dağılış desenlerini anlamak, ekstrem sıcaklık (sıcak ve soğuk) olaylarını belirlemek ve ekstrem olayların bölgesel özelliklerini incelemektir. Çalışma kapsamında verilerin temel istatistikler tanımlanmıştır. Maksimum ve minimum sıcaklık verilerinde herhangi bir önemli değişikliğin olup olmadığına karar vermek için Kruskal-Wallis (K-W) sınaması uygulanmıştır. Verilerdeki değişkenliğin doğası ve büyüklüğünü anlamak için Mann-Kendall (M-K) sıra ilişki katsayısı yöntemi kullanılmıştır. Sıcaklık verilerine uygulanan Kruskal-Wallis test istatistiğine göre özellikle sıcaklıklarda istasyonların çoğunda yaz mevsiminde istatistiksel olarak anlamlı inhomojenlik gözlenmiştir. M-K test istatistiğine göre, sıcaklık ekstremlerinde (yaz günü, tropikal gece, ekstrem sıcak gün, sıcak gün) istatistiksel olarak anlamlı bir artş̧ bulunur.

Central Anatolia Region is one of seven geographical regions of Turkey. The area covering the internal parts of Turkey, is located in 13 provinces. In the study, 52 station data were used to represent the entire geography of the region. In general, the trend to increasing at the air temperatures (especially at night temperatures) is remarkable. In recent times, hot-cold weather fluctuations and severe summer droughts have been more frequently, are more likely to cause significant socio-economic problems. The aim of the study is to understand the spatial and temporal distribution patterns of the temperatures in the summer and winter of the Central Anatolia Region, to determine extreme temperature (hot and cold) events and to examine the regional characteristics of extreme events. Basic statistics of the temperature data are defined within the scope of the study. The Kruskal-Wallis ( $K-W)$ test was performed to determine whether there was any significant change in the maximum and minimum temperature data. The Mann-Kendall (M-K) order correlation coefficient method was used to understand the nature and magnitude of variability in the data.According to the Kruskal-Wallis test statistic, statistically significant inhomogeneity was observed especially in the summers of the stations in most of the temperatures. According to the MK test statistic, there is a statistically significant increase in the temperature extremes (summer day, tropical night, extreme warm day, warm day).

\section{Giriş}

Yerküre iklimi, jeolojik devirler boyunca çeşitli değişimlere uğramıştır. Bu değişimlerin süreleri milyon ile ifade edilen yıllardan bin ile ifade edilen salınımlara kadar değişik ölçeklerde olmuştur. İklimlerdeki bu doğal değişim süreci bugün de devam etmektedir. Ancak bugünü eski çağlardan ayıran fark, insanoğlunun doğal sürece olan müdahalesidir (Gönençgil, 2008).

IPCC, beşinci değerlendirme raporunun sonuçlarına göre, Yerküre yüzey sıcaklıkları 1850'den beri artmaktadır. Her bir on yıl bir öncekinden daha sıcak olacak şekilde sıcaklıklar devamlı bir artış göstermiştir. Özellikle, son otuz yıldır Yerküre yüzey sıcak- lıkları ardı ardına daha sıcak olmuştur. Küresel ortalama birleştirilmiş kara ve okyanus yüzey sıcaklıkları, 1880-2012 döneminde $0.85^{\circ} \mathrm{C}$ artmıştır. Tek en uzun veri setine bağlı olarak, $1850-1900$ ve $2003-2012$ dönemleri arasındaki toplam artş $0.78^{\circ} \mathrm{C}^{\prime} \mathrm{dir}$ (IPCC, 2014).

Ekstrem sıcaklık olayları, uzun süreli sıcak veya soğuk hava akışları iklim sistemi ve insan konforu açısından önemli etkilere sahiptir. İklim değişikliğinin kabul edilen etkilerinden bir olan ekstrem hava olayları Yerküre'nin bir çok bölgesinde görülmektedir. Bu ekstrem sıcaklık olayları özellikle bazı alanlarda çoğun- 
lukla artış yönünde belirgin bir eğilim göstermektedir. Yerküre'nin değişen kara ve deniz suyu sıcaklıkları ile tümleşik yüzey sıcaklıkları son yıllarda artı̧ yönünde önemli değişiklikler göstermektedir.
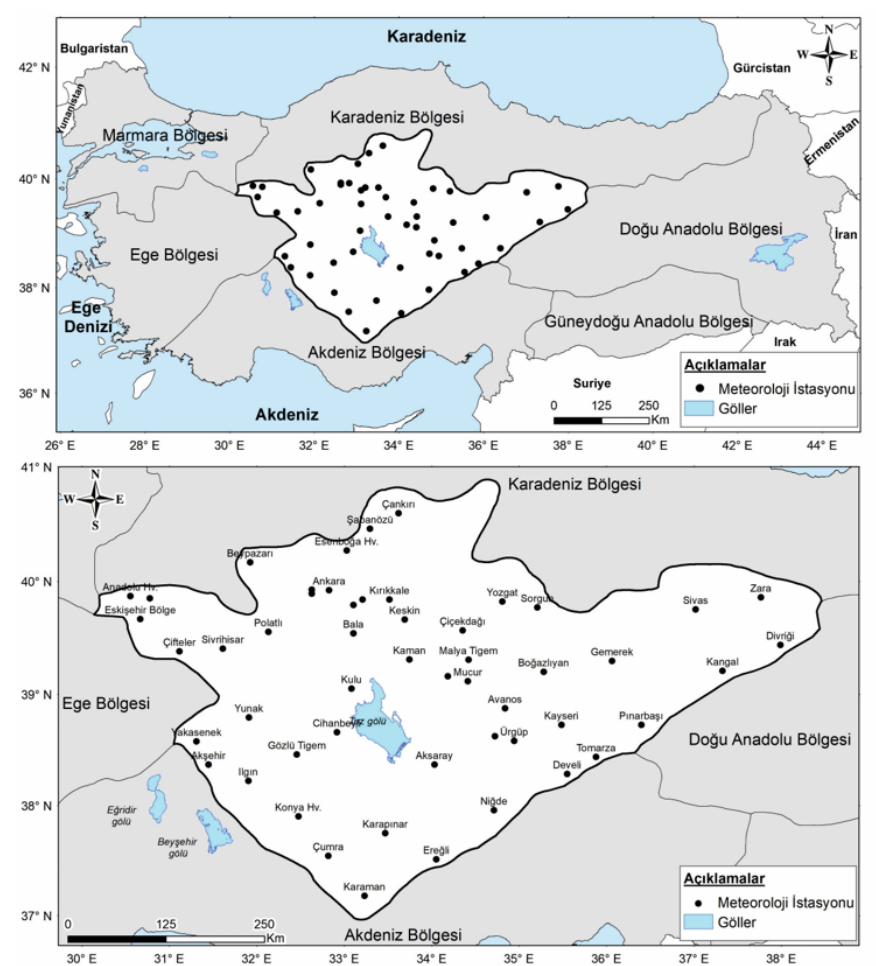

Şekil 1. Çalışma alanının yerbulduru haritası.

Figure 1. Location map of the study area.

1998'den 2014 yılına kadar iklimin doğal değişkenliği nedeniyle ısınmanın yavaşlamasına rağmen, son yıllarda yerküre iklim sisteminin yaklaşık $1 \mathrm{~W} / \mathrm{m}^{2}$ 'lik net enerji kazancına yol açan üst atmosferdeki sabit enerji dengesizliği nedeniyle deniz seviyesinde herhangi bir yükselme görülmemiştir (Hu ve Bates, 2018). IPCC beşinci raporuna göre, Avrupa'da ortalama sıcaklıklarda artişlar devam etmektedir. Bölgesel ve mevsimsel sıcaklık artış farkları Kuzey Avrupa'da daha büyüktür. 1950'den beri yüksek sıcaklık ekstremleri (sıcak günler, tropikal geceler ve sıcak hava dalgaları) daha sık hale gelirken, düşük sıcaklık ekstremleri (soğuk hava dalgası, donlu günler) daha az yaşanmaktadır (Kovats, vd., 2014).

Küresel ya da bölgesel ölçekte yaşanan sıcaklık değişkenlikleri tüm ekosistemler üzerinde dramatik bir etkiye sahiptir. Yağış değişkenliğinin fazla olduğu alanlarda sıcaklık ve yağış miktarlarında yaşanan ya da yaşanabilecek değişimlerin sonuçları da büyük olacaktır.

Akdeniz havzası, hem IPCC değerlendirmelerine hem de yapılan birçok çalışmaya göre iklim değişikliği etkilerine karşı en hassas olan alanlardan biridir (Maheras vd., 2006; Kuglitsch vd., 2010). Doğu Akdeniz ve Orta Doğu'nun kuzey kesimi $6-10{ }^{\circ} \mathrm{C}$ arasında artan ISı dalgası genliğine maruz kalabilir ve güney kesimi ise 2-3 ayını daha fazla birleşik sıcak günler ve tropikal geceler yaşayabilir (Zittis vd., 2015).

İç Anadolu Bölgesi, sıcaklık ekstremlerinin belirgin yaşandığı bölgelerden biridir. Bu çalışmada, ekstrem sıcaklıklardaki alansal ve zamansal değişkenlikleri doğasını ve büyüklüğünü anlamaya çalışılmıştır. Bu nedenle de bölge genelinde oldukça fazla istasyon sayısı ile yaşanan sıcaklık ekstremleri değerlendirilmiştir. Sıcaklık afetleri hakkında bölge genelinde elde edilen bilgi, ekstrem sıcaklık olaylarını anlamaya, riskleri azaltmaya ve etkilerini yönetme kolaylığı sağlayacaktır.

\section{Veri ve Yöntem}

Çalışma alanı, Türkiye'nin iç kesimlerini kapsayan İç Anadolu Bölgesidir. Bu coğrafi bölgede 13 il merkezi yeralır. Çalışma kapsamında bölgenin tüm coğrafyasını temsil edecek şekilde Meteoroloji Genel Müdürlüğ̈’nden sağlanan 52 istasyonun sıcaklık verisinden yararlanılmıştır (Şekil 1 ve Tablo 1 ).

Çalışmada kullanılan günlük sıcaklık verilerinin uzunlukları istasyonlara göre değişmektedir. İstasyonların büyük bir kısmı 1965-2017 dönemine ait sıcaklık verilerini kapsarken, en kısa gözlemlerin olduğu istasyonların ise verileri sadece 2007-2017 dönemini kapsar.

Tablo 1. Çalışmada kullanılan istasyonlara ait enlem, boylam, yükselti ve veri bilgileri.

Table 1. Latitude, longitude, elevation and data information belonging to the stations used in the study.

\begin{tabular}{|c|c|c|c|c|}
\hline İstasyon adı & Enlem & Boylam & Yükselti (m) & Veri Aralığı \\
\hline Çankırı & 40.6086 & 33.6102 & 751 & $1965-2017$ \\
\hline Sivas & 39.7437 & 37.0020 & 1294 & $1965-2017$ \\
\hline Anadolu Havaalanı & 39.8119 & 30.5287 & 787 & $1991-2012$ \\
\hline Eskişehir Havaalanı & 39.7810 & 30.5797 & 786 & $2000-2017$ \\
\hline Eskişehir Bölge & 39.7656 & 30.5502 & 801 & $2007-2017$ \\
\hline $\begin{array}{l}\text { Esenboğa } \\
\text { Havalimanı }\end{array}$ & 40.1240 & 32.9992 & 959 & $1965-2017$ \\
\hline Etimesgut & 39.9559 & 32.6854 & 806 & 1995-2017 \\
\hline Ankara & 39.9727 & 32.8637 & 891 & $1965-2017$ \\
\hline Kırıkkale & 39.8433 & 33.5181 & 751 & $1965-2017$ \\
\hline Elmadağ Radar & 39.7985 & 32.9716 & 1807 & 2007-2017 \\
\hline Yozgat & 38.8205 & 34.8159 & 1301 & $1965-2017$ \\
\hline Kırşehir & 39.1639 & 34.1561 & 1007 & $1965-2017$ \\
\hline Gemerek & 39.1850 & 36.0805 & 1182 & $1965-2017$ \\
\hline Cihanbeyli & 38.6503 & 32.9226 & 969 & $1965-2017$ \\
\hline Aksaray & 38.3705 & 33.9987 & 970 & $1965-2017$ \\
\hline Nevşehir & 38.6163 & 34.7025 & 1260 & $1965-2017$ \\
\hline Kayseri & 38.6870 & 35.5000 & 1094 & $1965-2017$ \\
\hline Akşehir & 38.3688 & 31.4297 & 1002 & $1965-2017$ \\
\hline Konya Havaalanı & 37.9837 & 32.5740 & 1031 & $1965-2017$ \\
\hline Karaman & 37.1932 & 33.2202 & 1018 & $1965-2017$ \\
\hline Ereğli Konya & 37.5255 & 34.0485 & 1046 & 2004-2017 \\
\hline Nigde & 37.9587 & 34.6795 & 1195 & $1965-2017$ \\
\hline Şabanözü & 40.4742 & 33.2857 & 1060 & 2006-2017 \\
\hline Etimesgut & 39.9500 & 32.6833 & 806 & 1965-1991 \\
\hline Beypazarı & 40.1608 & 31.9172 & 682 & $1965-2017$ \\
\hline Sorgun & 39.8016 & 35.1805 & 1116 & $1988-2017$ \\
\hline Elmadağ Barutsan & 39.9200 & 33.2125 & 1102 & 2010-2017 \\
\hline Zara & 39.8928 & 37.7473 & 1338 & $1965-2017$ \\
\hline Çifteler & 39.3659 & 31.0209 & 900 & 2004-2017 \\
\hline Sivrihisar & 39.4453 & 31.5354 & 1070 & $1965-2017$ \\
\hline Polatlı & 39.5834 & 32.1624 & 886 & $1965-2017$ \\
\hline Bala & 39.5546 & 33.1089 & 1250 & 2004-2017 \\
\hline Keskin & 39.6682 & 33.6118 & 1140 & $1977-2017$ \\
\hline Çiçekdağı & 39.6067 & 34.4235 & 900 & $1972-2017$ \\
\hline Divriği & 39.3618 & 38.1142 & 1121 & $1965-2017$ \\
\hline Malya TIGEM & 39.3038 & 34.3421 & 1127 & 2007-2017 \\
\hline Kulu & 39.0788 & 33.0657 & 1005 & $1965-2017$ \\
\hline Kaman & 39.3652 & 33.7064 & 1075 & $1966-2017$ \\
\hline Mucur & 39.0602 & 34.3767 & 1074 & 2004-2017 \\
\hline Boğazlıyan & 39.1897 & 35.2532 & 1070 & $1965-2017$ \\
\hline Kangal & 39.2428 & 37.3890 & 1521 & 1966-2017 \\
\hline Yunak & 38.8205 & 31.7258 & 1148 & 1971-2017 \\
\hline Pınarbaşı & 38.7215 & 36.3904 & 1542 & 1965-2017 \\
\hline Yakasenek & 38.5529 & 31.1730 & 1054 & $2005-2017$ \\
\hline Ilgın & 38.2763 & 31.8940 & 1036 & 1969-2017 \\
\hline Avanos & 38.7200 & 34.8538 & 951 & $1997-2017$ \\
\hline Ürgüp & 38.6218 & 34.9144 & 1068 & $1972-2017$ \\
\hline Develi & 38.3744 & 35.4797 & 1204 & $1965-2017$ \\
\hline Tomarza & 38.4522 & 35.7912 & 1402 & $1965-2017$ \\
\hline Gözlü TİGEM & 38.4919 & 32.4563 & 111 & 2007-2017 \\
\hline Çumra & 37.5658 & 32.7900 & 1014 & $1972-2017$ \\
\hline Karapınar & 37.7143 & 33.5267 & 996 & $1965-2017$ \\
\hline
\end{tabular}


Uzun olan veriler, sıcaklık indislerinin zamansal değişimlerini değerlendirmek ve yorumlamak için diğer kısa süreli olan gözlemler ise sıcaklık indislerin alansal dağılışının homojen olması amacıyla haritalanma aşamasında değerlendirilmiştir. Böylece sıcaklık indislerinin alansal olarak daha tutarlı bir desen sergilemesi amaçlanmıştr. Çalışma kapsamında kullanılan veri aralığı değerlendirildiğinde istasyonların \%67'si kesintisiniz olarak 35 yılın üzerindedir. Bu istasyon verileri çalışmanın temelini oluşturan alansal değişkenliği açıklamak için kullanılmıştır.

İklim değişikliği etkilerinin gözlenebildiği bu indislerden günlük sıcaklıklar için kullanılanlar liste halinde sunulmuştur (Tablo 2). İndisler, her bir istasyon için kendi uzun süreli verileri kullanılarak hesaplanmıştır. Sıcaklık indislerinin uzun süreli eğilimleri Mann-Kendall (M-K) trend analizi ile hesaplanmış ve eğilim desenlerinin alansal dağılış desenleri gösterilmiştir.

Tablo 2. Çalışma kapsamında kullanılan sıcaklık indisleri (Alexander vd., 2006 Frich vd., 2002; Klein Tank ve Können, 2003).

Table 2. Temperature indices used in the study (Alexander vd., 2006; Frich vd., 2002; Klein Tank ve Können, 2003).

\begin{tabular}{lll}
\hline $\begin{array}{c}\text { Sıcaklık } \\
\text { Indisi }\end{array}$ & \multicolumn{1}{c}{ Açıklama } & \multicolumn{1}{c}{ Tanım } \\
\hline Mak $>25$ & Maksimum sıcaklığın $>25^{\circ} \mathrm{C}$ olduğu günler & Yaz günü \\
Min $>20$ & Minimum sıcaklığın $>20^{\circ} \mathrm{C}$ olduğu günler & Tropikal gece \\
Min $<0^{\circ} \mathrm{C}$ & Minimum sıcaklığın $<0^{\circ} \mathrm{C}$ olduğu günler & Donlu gün sayıları \\
Mak $<0^{\circ} \mathrm{C}$ & Maksimum sıcaklığın $<0^{\circ} \mathrm{C}$ olduğu günler & Buzlu gün sayıları \\
Min $<1^{\text {st }}$ & Minimum sıcaklığın $<1^{\text {st }}$ yüzdebirlik olduğu günler & Ekstrem serin \\
Min $<5^{\text {th }}$ & Minimum sıcaklığın $<5^{\text {th }}$ yüzdebirlik olduğu günler & gece \\
Mak $>99^{\text {th }}$ & Maksimum sıcaklığın $>99^{\text {th }}$ yüzdebirlik olduğu günler & Ekstrem sıcak gün \\
Mak $>95^{\text {th }}$ & Maksimum sıcaklığın $>95^{\text {th }}$ yüzdebirlik olduğu günler & Sıcak gün \\
\hline
\end{tabular}

İç Anadolu Bölgesi'ndeki sıcaklık indislerindeki eğilimler, MannKendall (M-K) sıra ilişki katsayısı yöntemi kullanılarak belirlenmiştir. Mann-Kendall sıra korelasyon istatistiği tau'nun $(\tau)$ hesaplanmasında, N ve P'den türetilerek aşağıdaki denklem ile elde edilir. M-K sıra ilişki katsayısı $\tau$ 'nun hesaplamasında, analiz edilen xi elemanlı orijinal gözlem dizisinin yerine, onların küçükten büyüğe dizilmesiyle elde edilen sıra numaralarından oluşan ki dizileri temel alınır. İkinci olarak $P$ istatistiği aşağıdaki gibi hesaplanır;

$$
\begin{gathered}
P=\sum_{i=1}^{n} n_{i} \\
\tau=\frac{4 P}{N(N-1)}-1 \\
\tau_{(t)}=0 \pm t_{g} \frac{(4 N+10))}{9 N(N-1)}
\end{gathered}
$$

т'nun anlamlılık sınaması, yukarıdaki eşitlikle gösterilir. Mann Kendall sınama sonuçlarındaki istatistiksel anlamlılıklar, \%5 ve $\% 1$ anlamlılık düzeylerine göre belirlenmiştir. Hesaplanan $\tau$ değerinin, $\% 5$ ya da $\% 1$ düzeyinde anlamlı ve 0 'dan büyük olması durumunda artan, 0 'dan küçük olması durumunda ise veri dizisinde azalan yönde bir eğilimden bahsedilebilir (Mann, 1945; Kendall, 1975).

\section{Sıcaklık İndislerinin Alansal Desenleri}

Çalışma kapsamında, i̇ç Anadolu Bölgesinin tropikal gece, yaz günü, yüksek sıcaklık günü, donlu gün, buzlu gün, ekstrem sıcak gün, sıcak gün, ekstrem soğuk ve soğuk gün indisleri hesaplan- mıştır. Her bir indisin alansal dağılışını göstermek için haritalar üretilmiştir. Alansal dağılış haritaları, istasyon verilerinin farklı uzunluklarda olması nedeniyle her istasyonun indis değerlerini yansıtacak şekildedir.

Yaz günü indisi, gün içinde yaşanan en yüksek sıcaklıkların $25^{\circ} \mathrm{C}^{\prime}$ den fazla olduğu günlerdir. İç Anadolu Bölgesi'nde yaz günü indisinin alansal dağılışı incelendiğinde yaz günlerinin homojen bir dağılış göstermediği dikkat çekicidir. Yaz günü sayıları bölge genelinde 42-84 gün aralığında yaşanmaktadır. En düşük ortalamalar, 42 gün ile çalışma alanının en yüksek noktası olan $1807 m$ rakımı ile Elmadağ Radar istasyonundadır. Bu istasyon dağ iklim koşullarını yansıtması bakımından önemlidir. Yaz günü sayıları İç Anadolu Bölgesi'nin doğusunda, özellikle Bozok platosu ve doğusunda en düşük değerlere sahiptir. Bu alan, Karadeniz Bölgesi ile olan sınırında Akdağlar, Yıldız Dağı, Akdeniz ve Doğu Anadolu Bölgesi'yle olan sınırında Tahtalı Dağları ile Doğu Anadolu Bölgesi'yle olan sınırında Tecer Dağları ile sınırlanan ve ortalama yükseltisi 1000 m üzerinde olan platoluk bir sahadır. En yüksek yaz günü sayıları, Ankara ili çevresindeki istasyonlarda gözlenmektedir ayrıca bölgenin güneyi Konya ovası çevresinde yaz günü sayıları yüksektir (Şekil 2).

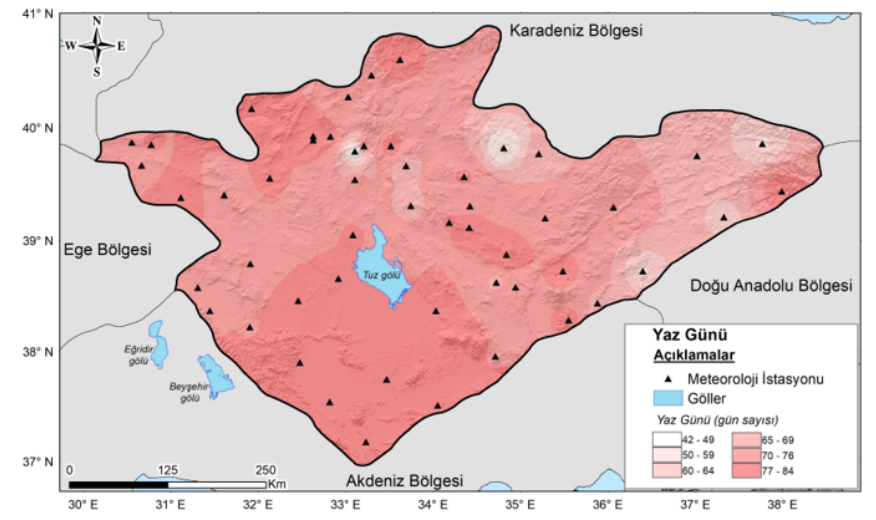

Şekil 2. Yaz günü sayılarının alansal dağılışı.

Figure 2. Spatial distribution of the numbers of summer day.

Tropikal gece, gün içinde yaşanan en düşük sıcaklıkların $20^{\circ} C^{\prime}$ den büyük olduğu günlerdir. Tropikal geceler yüksek nüfusa sahip olan alanlar çevresinde yoğunlaşmıştır. Ortalama tropikal gecelerin en yüksek olduğu istasyonlar çalışma alanının kuzeybatısında yoğunluk gösterir. Türkiye'nin önemli metropollerinden Ankara ve çevresinde oldukça yüksek tropikal gecelere rastlanırken, en düşük tropikal geceler kırsal özellik gösteren istasyonlarda yaşanmaktadır. Bu indis, Türkiye genelindeki ısınmaların en belirgin olduğu sıcaklıklara aittir. Yaz minimum sıcaklıklarındaki artışlar Türkiye genelindeki anlamlı ısınma eğilimlerinin en belirgin olduğu veri dizisidir. Tropikal geceler bölgenin kuzey ve bat kesimlerinde daha çok yaşanmaktadır. En düşük tropikal gece sayıları bölgenin doğusundaki platoluk sahalardadır (Şekil 3).

Donlu gün, minimum sıcaklıkların, günün herhangi bir anında $0^{\circ} C^{\prime}$ nin altına düştüğü gün olarak tanımlanır. Donlu gün sayıları İç Anadolu Bölgesi'nin batısından doğusuna doğru genel olarak bir artış gösterir. En düşük donlu gün sayılarına, istasyon rakımlarının az olduğu ovalarda bulunan istasyonlarda ve yüksek nüfusa sahip olan şehirleşmenin yoğun olduğu alanlar çevresinde rastlanır. Kentlerin yoğunlaştı̆̆ı alanlarda donlu gün sayıları belirgin olarak azalır. Daha önce yapılan çalışmalar ile benzer ola- 


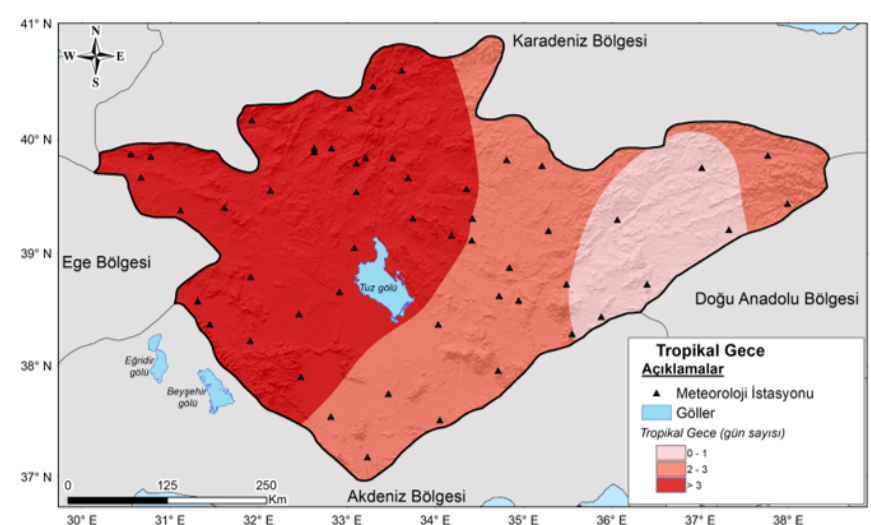

Şekil 3. Tropikal gece sayılarının alansal dağılışı.

Figure 3. Spatial distribution of the numbers of tropical night.

rak kırsal ve kentsel alanlar çevresinde belirgin farklılıklar bulunur. Örneğin; Çiçek (2005) çalışmasında Ankara'da şehir ve kırsal alanlar arasındaki yıllık ortalama sıcaklık farkını $2.01^{\circ} \mathrm{C}$ olarak belirtmiştir. Bu durum özellikle Ankara gibi metropol olan şehirler ve yakın çevresinde donlu gün sayılarının belirgin bir şekilde düşmesine neden olur. Bölgenin doğusunda, yükseltinin fazla olduğu platoluk sahalar ve küçük ölçekli kentsel yerleşimlerin olduğu alanlarda donlu gün sayıları en yüksek değerlere ulaşır (Şekil 4).

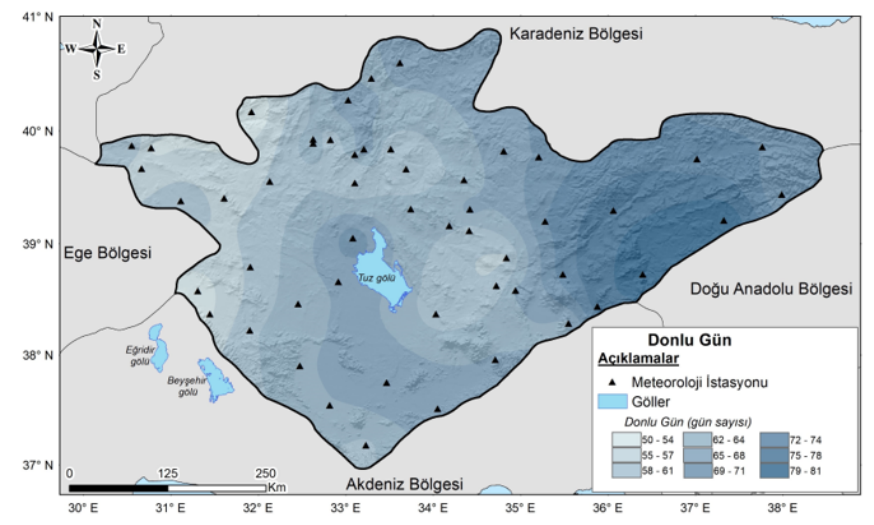

Şekil 4. Donlu gün sayılarının alansal dağılışı.

Figure 4. Spatial distribution of the numbers of frost day.

Buzlu günler, maksimum sıcaklığın bütün gün boyunca $0^{\circ} C^{\prime}$ nin altında olduğu günlerdir. Buzlu günler, bölgenin batısından doğusuna doğru artar. Buzlu günlerin en fazla görüldüğü yerler Sivas çevresindeki istasyonlardır (Şekil 5). Bu istasyonların bulundukları alanlar ve yakın çevreleri $1200 \mathrm{~m}$ 'den yüksek platoluk sahalardır. Bölgenin dağlık alanları dışındaki en yüksek rakımına sahip olan Sivas çevresindeki istasyonlarda (Kangal, Zara, Divriği ve Pınarbaşı) yaklaşık olarak bir ay buzlu gün yaşanır. Kentsel alan özelliği ile Ankara çevresinde yıl içindeki buzlu gün sayıları 15 günün altındadır. Kentsel özelliğinin yanında bölgenin bat kesimlerinin topoğrafyası dağıık alanları dışında $1000 m^{\prime}$ nin altında ova ve platoluk yüzeylerden oluşur. Benzer şekilde topografyanın daha sade olduğu Aksaray- Avanos çevresi benzer şekilde en düşük buzlu gün ortalamaları 15 günün altında yaşanmaktadır.

Donlu ve buzlu geçen günler özellikle tarımsal faaliyetler ve bitki hayat bakımından önemlidir. Donlu ve buzlu geçen günler bölgenin yüksek engebeye sahip olan alanlarında yayılış gösterirler. Bölgenin yüksek platoluk alanlarında kış mevsiminin 2/3'ünde don olayı egemendir. Buzlu günler ise bu yüksek kesimlerde kış mevsiminin yaklaşık 1/3'ünü oluşturur. Karasal bir iklime sahip olan bölge genelinde don olayı oldukça önemli bir yer tutar.

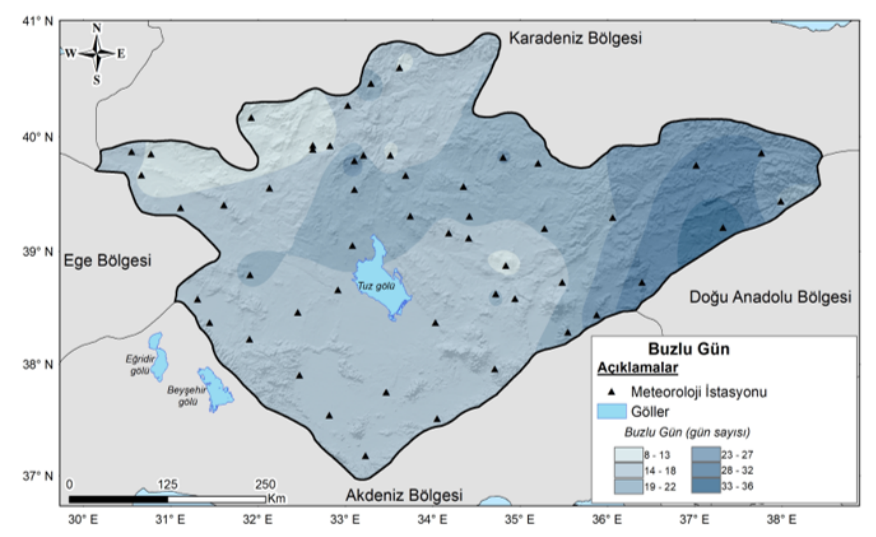

Şekil 5. Buzlu gün sayılarının alansal dağılışı.

Figure 5. Spatial distribution of the numbers of ice day.

Serin geceler, yaz mevsimi minimum sıcaklık verilerinin uçta, en düşük sıcaklıklara sahip olduğu günlerdir (<5th persantil). Serin gece sayılarının alansal dağııışı incelendiğinde en yüksek gün ortalamalarına, topoğrafyanın homojenlik gösterdiği, bölgenin doğusunda rastlanır. Bu alandaki istasyonların yükseltisi $1500 \mathrm{~m}$ 'nin üzerindedir. Yaz mevsiminde, serin geceler en fazla bölgenin en engebeli topoğrafyasına sahip olan doğu kesimindedir. Bu alanlar çoğunlukla geniş platoluk sahalardan oluşur (Şekil 6). Yaz mevsiminde, yükselti serin gecelerin belirlenmesinde en belirleyici faktördür. Yükseltinin belirgin olarak fazla olduğu ve nüfus yoğunluğunun az olduğu bölgenin doğusunda serin geceler batiya göre 3-4 gün daha fazladır. En düşük serin geceler ise İç Anadolu Bölgesi'nin kuzeybatısında yaşanır. Burada yeralan Yukarı Sakarya ovaları, bölgenin en az yükseltisine sahip olan alanlardandır. Ayrıca kentsel alanlar, gece sıcaklıklarının daha sıcak yaşanmasına neden olacak kentsel ıSı adaları oluşturarak gece konforunun da azalmasını sağlarlar (Çiçek, 2005; Çiçek ve Doğan, 2005).

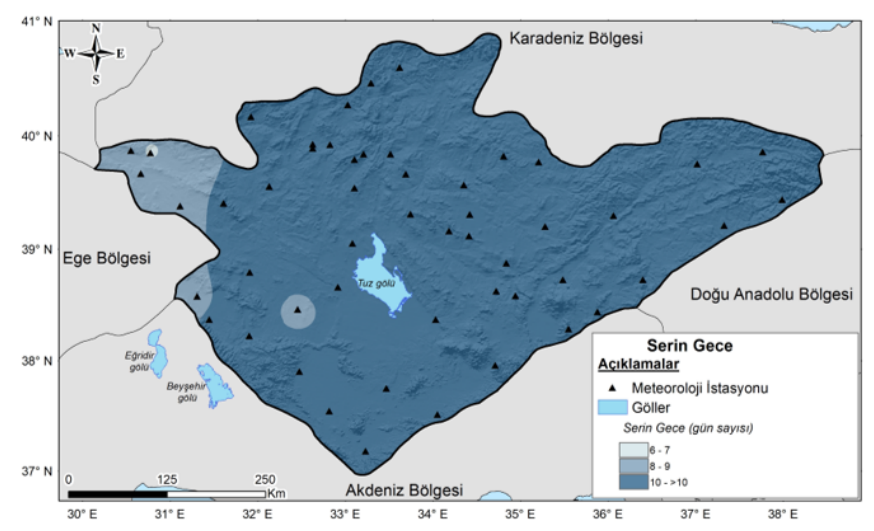

Şekil 6. Serin gece sayılarının alansal dağılışı.

Figure 6. Spatial distribution of the numbers of cold night.

Ekstrem serin geceler, yaz mevsimi minimum sıcaklık verilerinin en düşük yaşanan, en uç değerdeki günlerdir (<1st persantil). Ekstrem serin geceler, her istasyonun uzun yıllık verileri ile her bir istasyon için hesaplanmıştır. Ekstrem serin gecelerin alansal 
dağılışında, en düşük değerler Tuz gölünün batısında kalan alanda gözlenir. En fazla ekstrem serin geceler topoğrafyanın yüksek olduğu Yozgat-Sivas illerindeki istasyonlarda gözlenir. Bu alanlar aynı zamanda yoğun nüfusa sahip olmayan istasyonlar oldukları için kentsel ısı adası etkilerinden uzaktırlar. İç Anadolu Bölgesi'nin batı ve doğusu arasındaki ortalama 2-2.5 günlük ekstrem serin gece farkları bat kesiminde yeralan istasyonlarda yaz mevsimindeki ısınma eğilimlerinin daha kuvvetli olduğunun da bir göstergesidir (Şekil 7).

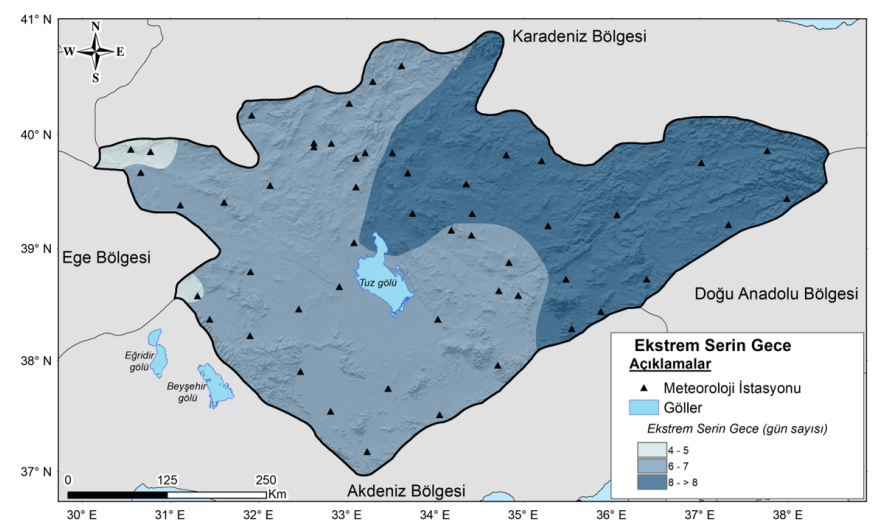

Şekil 7. Ekstrem serin gece sayılarının alansal dağılışı.

Figure 7. Spatial distribution of the numbers of extreme cold night.

Ekstrem sıcak günlerin en yüksek değerleri, i̇ç Anadolu Bölgesi'nin doğusunda yoğunlaşmıştır. Anadolu Havaalanı, Eskişehir Havaalanı ile dağ istasyonu olan Elmadağ istasyonlarında en düşük ekstrem sıcaklara sahiptir. Bu istasyonlarda yaz mevsimi boyunca ortalama 5.5-6 gün yaşanır. Bölgenin güneyi ve kuzeyinde ekstrem sıcak gün sayıları 7 günün üzerindedir. Bölge genelinde en yüksek ekstrem sıcaklıklar 1200m'nin üzerindeki rakımıyla çoğunlukla geniş platoluk alanlarda yer alan istasyonlarda yaşanır. Karasallığın etkili olduğu bu alan yaz mevsimi gündüz en yüksek sıcaklıklarının yaşandığı alanlara karşılık gelir (Şekil 8). Yaz mevsiminde bölgede yaşanan aşırı sıcaklıklar karasallığın etkisinin en büyük göstergesidir. Yaz mevsiminde Konya ve çevresinde güney ve doğu yönlü rüzgarlar etkilidir. Özellikle, yaz mevsiminde Muson alçak basıncının etki alanını kuzeye doğru kaydırmasıyla birlikte Türkiye'nin çoğunlukla Güneydoğu Anadolu Bölgesi'ni etkisi altına alan sıcak ve kavurucu samyeli rüzgarı Tuz gölünün doğusu ve güneyinde de etkinliğini hissettirir.

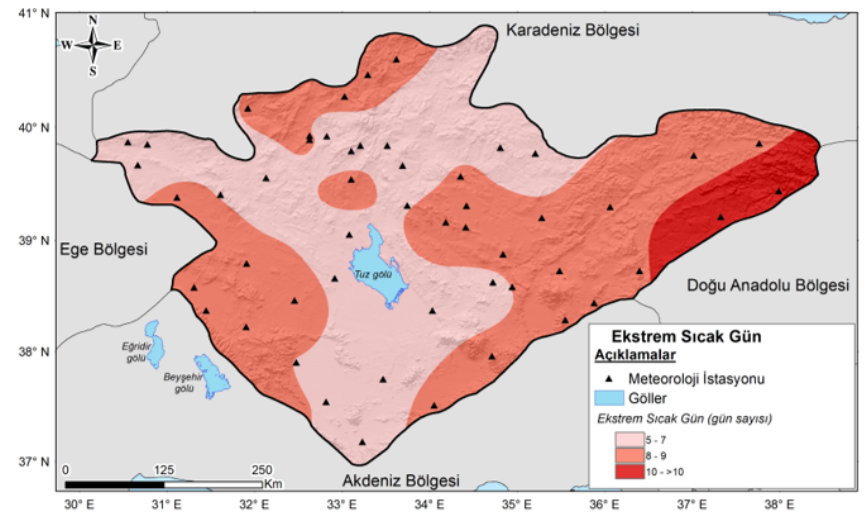

Şekil 8. Ekstrem sıcak gün sayılarının alansal dağılışı.

Figure 8. Spatial distribution of the numbers of extreme warm day.

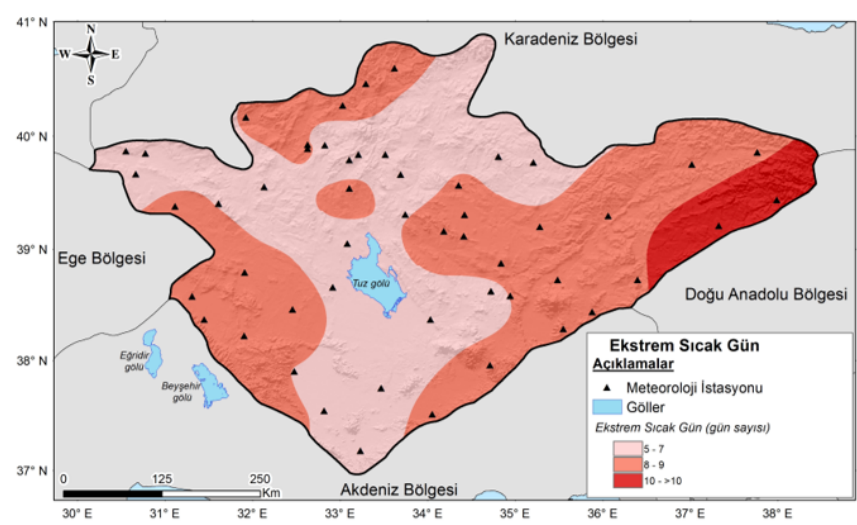

Şekil 9. Sıcak gün sayılarının alansal dağılışı.

Figure 9. Spatial distribution of the numbers of warm day.

Sıcak günler, maksimum sıcaklık verilerinin en yüksek yaşandığı uçtaki değerlerdendir. Sıcaklıklar genel olarak normal dağılım gösterirler. Sıcak günler, normal dağılımın en sıcak olan uçların \%95 olan kısmındaki maksimum uçtan ortalamaya daha yaklaşan değerlere karşılık gelir. Sıcak günlerin dağılışı, genel olarak ekstrem sıcak günlere benzer. İç Anadolu Bölgesi'nde en yüksek sıcak gün değerleri bölgenin güneyinde ve doğusundadır.

Yaz mevsiminde, Konya ve çevresinde, güney ve doğu sektörlü rüzgarlar yazın sıcak ve kavurucu etki yaparlar. Bu etki bazı köylerde "sam vurması" kelimesiyle ifade edilir (Erol, 1963). "Sam vurması" ekstrem sıcak ve sıcak günler üzerinde önemli bir etkiye sahiptir. Yaz mevsiminde artan yüksek sıcaklıklar, sıcak esen rüzgarlarla etkisini birleştirerek yöre ve çevresi için oldukça önemli sıkıntıya neden olmaktadır.

\section{Sıcaklık İndislerinin Zamansal Desenleri}

Çalışma alanında yer alan istasyonlara uygulanan Mann-Kendall eğilim analizine göre bölge genelinde yaz günü, tropikal gece, ekstrem sıcak gün ve sıcak gün indislerinde istatistiksel olarak anlamlı artış eğilimleri vardır (Tablo 3).

Tablo 3. Çalışma alanındaki istasyonların sıcaklık indislerine göre test istatistikleri.

Table 3. Test statistics based on the temperature indices of the stations in the study area.

\begin{tabular}{lcl}
\hline Sıcaklık İndisi & M-K u(t) değeri & Eğilim \\
\hline Yaz Günü & 4.97 & $\% 95$ güven aralığında artış eğilimi var \\
Tropikal Gece & 4.47 & $\% 95$ güven aralığında artı̧̧ eğilimi var \\
Donlu Gün & 0.02 & $\% 95$ güven aralığında artıŞ veya azalış yok \\
Buzlu Gün & -0.63 & $\% 95$ güven aralığında artıŞ veya azalış yok \\
Ekstrem Serin Gece & -0.57 & $\% 95$ güven aralığında artış veya azalış yok \\
Serin Gece & -0.63 & $\% 95$ güven aralığında artış veya azalış yok \\
Ekstrem Sıcak Gün & 3.66 & $\% 95$ güven aralığında artış eğilimi var \\
Sıcak Gün & 3.71 & $\% 95$ güven aralığında artış eğilimi var \\
\hline
\end{tabular}

Yaz günleri bölge genelinde ortalama 74 gün ile oldukça yüksek bir değere sahiptir. Yaz mevsiminin büyük bir kısmında maksimum sıcaklıklar bölge genelinde $25^{\circ} \mathrm{C}$ üzerinde geçmektedir. Indisin zamansal dağılışında $1990^{\prime} l a r d a n$ itibaren bir değişim göze çarpar. 2000 yılı bölge için yaz günlerindeki değişim noktasıdır. 2002'den itibaren ise bölge genelindeki yaz günü indisinde yaşanan artş, istatistiksel olarak anlamlı bir eğilime dönüşmüştür.

Tropikal geceler, İç Anadolu Bölgesi genelinde 2 gün ortalamasına sahiptir. Yaz mevsimi gece sıcaklıklarında ısınma eğilimleri her istasyonda belirgin değildir. 1998 yazı bölge geneli için 


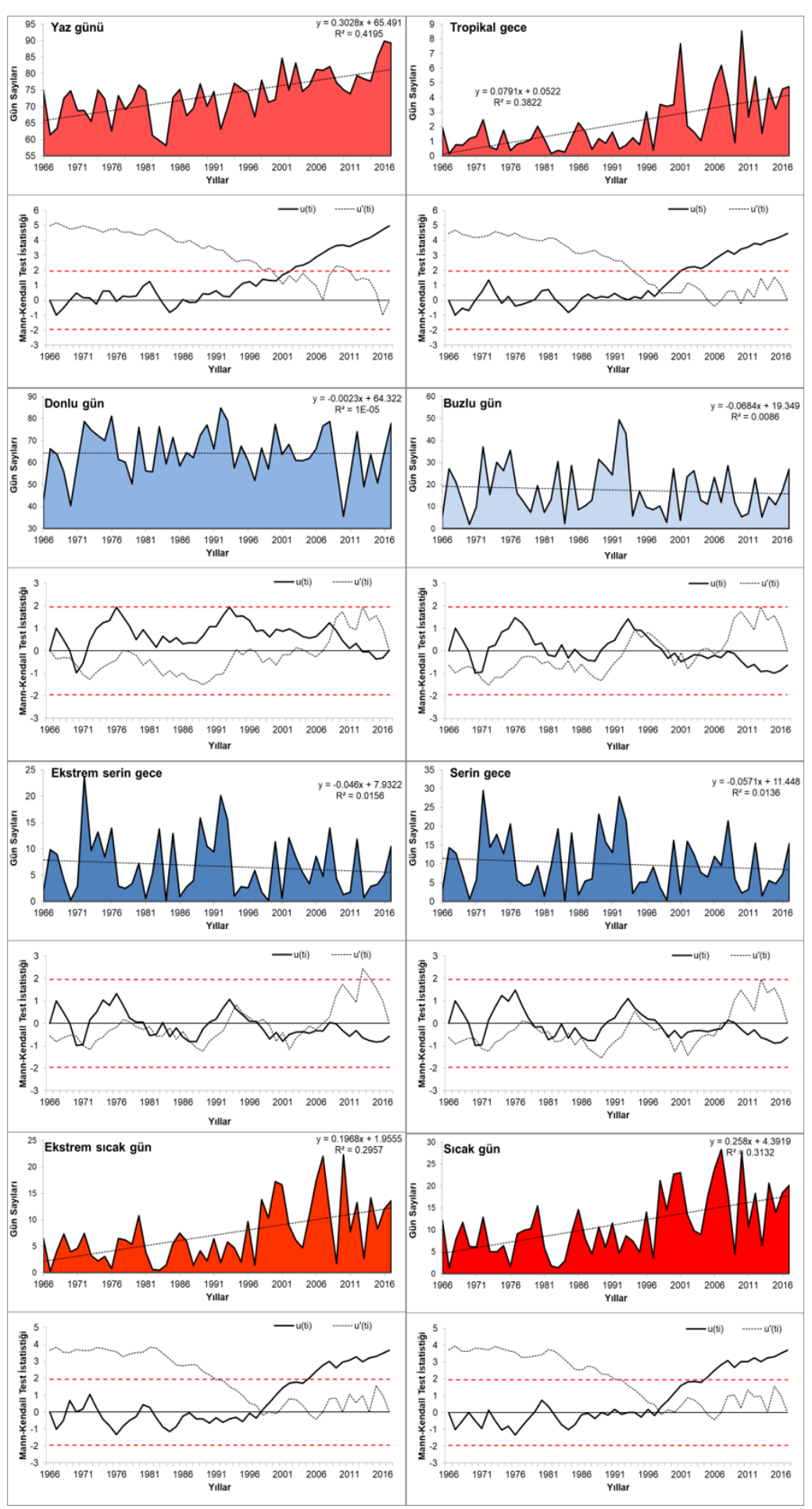

Şekil 10. Sıcaklık indislerindeki değişimlerin ve eğilimlerin zamansal değişimleri. Figure 10. Temporal changes and trends in temperature indices.

önemli değişiklik yılıdır. 2001 yılından itibaren tropikal gece sayılarında yaşanan artş̧ istatistiksel olarak anlamlıdır. Bölge genelindeki eğilim yaz günü ile benzerlik gösterir. Özellikle 2000 'li yılların başından itibaren önemli sıcak geçen geceler bölge genelinde sayıca artmaktadır.

Donlu günler, bölge genelinde kış mevsiminin oldukça soğuk geçtiğinin en önemli göstergesidir. Karasallık, bölge genelinde oldukça etkilidir. Kış mevsiminin yaklaşık 64 gününde minimum sıcaklıklar $0^{\circ} \mathrm{C}$ 'nin altında yaşanmaktadır. Donlu gün sayılarında yıllararası değişkenlikler görülse de istatiksel olarak anlamlı bir eğilim gözlenmemiştir.

Buzlu günler, anlamlı olmayan zayıf bir azalma eğilimi içermek- tedir. Kış mevsimi boyunca bölge genelinde 17 gün buzlu olarak yaşanmaktadır. Buzlu gün sayılarında gözlenen zayıf azalma eğilimi, bölge genelinde kış mevsimi maksimum sıcaklıklarının $0^{\circ} \mathrm{C}^{\prime}$ nin üzerinde yaşanmaya başladığının belirgin bir göstergesidir (Şekil 10).

Ekstrem serin gece ve serin geceler anlamlı olmayan zayıf bir eğilim içerir. Bölge genelinde, ekstrem serin geceler yaklaşık 6 gün, serin geceler ise yaklaşık 10 gün yaşanır. 1970'li yıllar ve 1990 'lı yıllar ekstrem serin ve serin gece sayılarının en fazla yaşandığı dönemlerdir. Son yıllarda serin yaşanan günlerde azalmalar dikkate değer düzeydedir.

Ekstrem sıcak günler, bölge genelinde anlamlı artı̧ın gözlendiği 
indis dizisidir. 1990'lı yılların ortalarından itibaren başlayan değişim ile birlikte 2000 'li yılların başlarından beri istatistiksel olarak bölge genelinde anlamlı artış eğilimleri yaşanmaktadır. Sıcak günler de ekstrem sıcak günler ile benzer bir eğilim gösterir. Sıcak gün indisindeki artş eğilimi 2000'lerden itibaren istatistiksel olarak anlamlıdır. Bölge genelinde yaz mevsiminde yaşanan ekstrem ve sıcak gün sayıları ortalama 7-11 gündür.

\section{Sonuçlar}

Türkiye'nin iç kesimlerinde yer alan İç Anadolu Bölgesi, kuzeyde Karadeniz, doğuda Doğu Anadolu, güneyde Akdeniz, batıda, Ege ve küçük bir alan ile Marmara Bölgeleri ile çevrilidir. Çaıışma alanındaki kayıt süreleri 30 yılı aşan istasyonların verisinden yararlanılarak analiz ve değerlendirmeler yapılmıştır. Buna göre istasyonların önemli bir kısmında iklim değişikliğinin son yüzyılda en önemli göstergelerinden biri olarak kabul edilen ekstrem yüksek ve düşük sıcaklıklar tespit edilmiştir.

İç Anadolu Bölgesi'nde en fazla yaz günleri rakımın az olduğu istasyonlarda gözlenir. İstasyon rakımlarının arttğı, bölgenin platoluk alanlarına doğru yaz günü sayıları azalır. Yükseltinin az olduğu istasyonlar ile platoluk alanlarda yeralan istasyonlar arasında ortalama 10-15 günlük fark bulunur. Tropikal gecelerin yaşandığı alanlar çoğunlukla yüksek nüfus yoğunluğunun sahip olan büyükşehirlerde bulunan istasyonlardadır. Yaz gecelerinde yaşanan ısınma topoğrafik faktörler ile de birleşince alçak olan alanlarda Isı adası oluşumunu şiddetlendirmektedir. Donlu ve buzlu günler, Akdeniz havzası genelinde olduğu gibi Türkiye'nin iç kesimlerinde ve platoluk alanlarda daha fazladır. Bölge genelinde de en yüksek rakıma sahip olan bölgenin doğusunda donlu ve buzlu gün sayıları fazladır. Yoğun nüfusa sahip olan yerleşmelerde donlu ve buzlu gün ortalamaları yaklaşık 10 gün daha fazla yaşanmaktadır. Ekstrem serin ve serin geceler bölge genelinde az nüfusa sahip olan alanlarda 3-4 gün daha fazla yaşanır. Ayrıca ekstrem serin geceler, serin gecelerden yaklaşık 4 gün daha az yaşanır. Ekstrem sıcak ve sıcak günler, i̇ç Anadolu Bölgesi'nin güneyinde, Tuz gölü çevresinde en yüksek değerlere sahiptir. Bu alan ve çevresi, Toros Dağlarını aşan hava akımlarının adyabatik olarak ısınmasıyla fön rüzgarı etkisinde kalır. Ayrıca, yaz mevsiminde genel atmosfer dolaşımının etkisiyle Güney- Güneydoğulu dolaşımın sıcak havasının etkisi altında kalır. Bölgenin güneyinde sıcak günler bölgenin diğer alanlarından 1-2 gün daha fazladır.

Sıcaklık indisleri ile belirlenen ekstremler bölge genelinde ısınma yönünde bir eğilimin varlığına işarettir. Sıcak geçen ekstrem günlerin sayısında yıllar arasında belirgin bir artı̧̧ gözlenirken, serin ya da soğuk geçen günler de ise azalma yönünde bir eğilim egemendir. Ayrıca, istasyonlardaki sıcak ekstremler çoğunlukla nüfus yoğunluğunun yüksek olduğu alanlar çevresinde dağılış gösterirler. Nüfus yoğunluğunun az olduğu ve topografyanın yüksek olduğu, platoluk sahalarda sıcak geçen ekstrem günler 2-5 gün daha az yaşanmaktadır.

\section{Kaynakça}

Alexander, L.V., Zhang, X., Peterson, T.C., Caeser, J., Gleason, B., Klein Tank, A.M.G., Haylock, M., Collins, D., Trewin, B., Rahimzadeg, F., Tagipour, A., Rupa Kumar, K., Revadekar, J., Griffiths, G., Vincent, L., Stephenson, D.B., Burn, J., Aguilar, E., Brunet, M., Taylor, M., New, M., Zhai, P., Rusticucci, M., Vazquez-Aguirre, J.L. (2006). Global observed changes in daily climate extremes of temperature and precipitation. Journal of Geophysical Research, 111, D05109, doi:10.1029/2005JD006290.

Çiçek, i. (2005). Ankara'da şehir ve kırsal sıcaklık farklarındaki değişiklikler (1970-2002). Fırat Üniversitesi Sosyal Bilimler Dergisi, Cilt: 15, Sayı: 2, 1-16.

Çiçek, i., Doğan, U. (2005). Ankara'da şehir isi adasının incelenmesi, Coğrafi Bilimler Dergisi, 3(1), 57-72.

Erol, O. (1963). iç Anadolu'da Haymana Tuzgölü Çevrelerinin Iklimi Hakkında. Ankara Üniversitesi, Dil ve Tarih Coğrafya Fakültesi Dergisi, Cilt 21, 3-4.

Frich, P., Alexander, L.V., Della-Marta, P., Gleason, B., Haylock, M., Klein Tank, A. M. G., Peterson T. (2002). Observed coherent changes in climatic extremes during the second half of the twentieth century. Climate Research, 19, 193-212.

Gönençgil, B. (2008). Doğal Süreçler Açısından Iklim Değişikliği ve Insan, Çantay Yayınevi, ISBN: 978-975-9060-50-3, İstanbul.

$\mathrm{Hu}, \mathrm{A}$., Bates, S.C. (2018). Internal climate variability and projected future regional steric and dynamic sea level rise. Nature Communications, 9, 1068, DOI: 10.1038/s41467-018-03474-8.

IPCC, 2014: Climate Change (2014). Synthesis Report. Contribution of Working Groups I, II and III to the Fifth Assessment Report of the Intergovernmental Panel on Climate Change [Core Writing Team, R.K. Pachauri and L.A. Meyer (eds.)]. IPCC, Geneva, Switzerland, $151 \mathrm{pp}$.

Klein Tank, A.M.G., Können, G.P. (2003). Trends in Indices of Daily Temperature and Precipitation Extremes in Europe 1946-1999. Journal of Climate, 16, 3665-3680.

Kuglitsch, F.G., Toreti, A., Xoplaki, E., Della-Marta, P.M., Zerefos, C.S., Turkes, M., Luterbacher, J. (2010) Heat wave changes in the eastern Mediterranean since 1960. Geophys Res Lett 37(4), L04802. doi:10.1029/2009GL041841.

Kovats, R.S., R. Valentini, L.M. Bouwer, E. Georgopoulou, D. Jacob, E. Martin, M. Rounsevell, and J.-F . Soussana. (2014). Europe. In: Climate Change 2014: Impacts, Adaptation, and Vulnerability. Part B: Regional Aspects. Contribution of Working Group II to the Fifth Assessment Report of the Intergovernmental Panel on Climate Change [Barros, V.R., C.B. Field, D.J. Dokken, M.D. Mastrandrea, K.J. Mach, T.E. Bilir, M. Chatterjee, K.L. Ebi, Y .O. Estrada, R.C. Genova, B. Girma, E.S. Kissel, A.N. Levy, S. MacCracken, P .R. Mastrandrea, and L.L. White (eds.)]. Cambridge University Press, Cambridge, United Kingdom and New York, NY , USA, pp. 12671326.

Maheras, P., Flocas, H., Tolika, K., Anagnostopoulou, C., Vafiadis, M. (2006). Circulation types and extreme temperature changes in Greece. Clim Res 30(2), 161-174. doi:10.3354/cr030161.

Zittis, G., Hadjinicolaou, P., Fnais, M., Lelieveld, J. (2016). Projected changes in heat wave characteristics in the eastern Mediterranean and the Middle East. Regional Environmental Change, 16, 18631876. 
